\title{
Smart Governance Implementation in Balikpapan City, East Kalimantan
}

\author{
Irfan Setiawan* \\ Faculty of Government Management, \\ Institut Pemerintahan Dalam Negeri (IPDN), Indonesia \\ Muh Ilham \\ Faculty of Law \\ Institute of Domestic Administration \\ M. Nawawi \\ Faculty of Government Management, \\ Institut Pemerintahan Dalam Negeri (IPDN), Indonesia
}

*Corresponding author: irfansetiawan@ipdn.ac.id

\begin{abstract}
The purpose of this study is to analyze the implementation of smart governance and the strengthening of city resources in order to support Smart Governance in the city of Balikpapan. This research adopts qualitative descriptive method using interview and observation techniques, and data were then analyzed. Results found that the application of smart governance in the city of Balikpapan was not yet well implemented so it was necessary to strengthen local government resources that include institutions, budgets, and IT (information technology) tools, in the dimensions of local government, and increase community participation and community use for the application in the community dimension.
\end{abstract}

Keywords: local resources; smart governance; information and communication technology; Balikpapan; Indonesia

\section{Introduction}

Regional innovation through the application of smart city in the implementation of regional government is one of the policies of the Indonesian nation state to prosper its people. The concept of a smart city has been accepted as a solution to development problems in many countries (Mauricio Bouskela et al. 2016: 135). Smart City is designed to be able to increase the productivity of people living in the area, by optimally utilizing information technology in all aspects of the administration of the regional government. In some countries, the development of information technology is directed to produce a new form of development approach, called smart city. The application of this concept can be realized in cities in Indonesia so that it can support the fulfillment of community needs and is also expected to help solve problems faced 
by a city, for example, in the aspects of transportation, education, health, population administration and other public services.

The local government needs to anticipate the growing population. Relatively rapid population growth through increased birth rates and urbanization in urban areas which can cause various problems, such as; congestion, the lack of residential land, poor quality public services, difficult to find parking locations, more garbage piled up, higher crime rates, and more. Therefore, to solve these problems so that the city feels comfortable for its people, it is necessary to solve problems intelligently. The smart solution is to implement the smart city concept.

In Indonesia, the policy regulations governing the development of the smart city concept is found in articles on regional innovation contained in Law number 23 of 2014 . Therefore, the application of the smart city concept in several regions in Indonesia differs from one another depending on several aspects of resources that the area has.

Balikpapan City is one of the cities which won the Smart City Index award in 2015 in the Kompas Daily version with a city category of 200,000 to 1 million people. Balikpapan City won second place after the city of Yogyakarta. There are three (3) aspects that form the basis of the assessment of the Smart City Kompas version, namely economic, social, and environmental. Cities that are considered to have applied intelligent concepts mean that they can meet the needs and solve the problems of citizens in the economic, social, and environmental fields. The Kompas daily evaluates and indexes 93 cities from 98 cities in Indonesia based on these three (3) aspects (www.balikpapan.go.id).

The award received was an effort and the result of hard work from stakeholders, namely the community, the private sector and the City government in building and empowering the city of Balikpapan. The smart city implementation in Balikpapan City is focused on the implementation of smart governance in city security, online public services, and the administration of online government.

Some programs implemented in supporting the implementation of smart governance in Balikpapan such as the smart governance development program are focused on public services and structuring of the bureaucracy. One public service program through the Hospital Online Reservation or "HORE" application program. The online service application is the result of a partnership between XL Axia-ta operators, School of Information Management and Computer in Balikpapan (STMIK Balikpapan), and Balikpapan City Health Office. Through the application, the people of Balikpapan can monitor and search for available rooms and services at the hospital first without having to go to sick Ruma, but simply accessing services online wherever and whenever. So far the HORE application has not been widely understood by many people in Balikpapan City, because its application is only downloaded by 50-100 users. This means, the application made by the Balikpapan Regional Government has not been widely used by the community. In fact, it is not a popular public service when compared to the population of Balikpapan City. This phenomenon indicates that the improvement in public services provided by the Balikpapan city government has not been widely known and used by the community. It is to be noted that budget resources for the provision of public services are not small.

The Balikpapan City Government also built an android-based service application, Digital Government Balikpapan to support an online government system. The fact is Digital 
Government Balikpapan has only been downloaded 100 times, and this indicates that only 100 out of 6283 Balikpapan City employees or around 1.59\% of Balikpapan City's employees use the service application. In the field of education services, the Balikpapan City Education Office developed the application of learning methods that use e-learning to be implemented gradually in several schools. The phenomenon of the application of e-learning is appropriate to support Balikpapan in implementing smart governance. But the obstacles that occur in the field is that, not all schools can implement e-learning because schools lack the facilities and infrastructure to support the implementation of e-learning. Another obstacle in implementing e-learning in Balikpapan City is that the community must be prepared to adjust the mindset first according to the understanding of the e-learning.

Another phenomenon that came up in the application of the concept of smart governance is in terms of the budget. The application of the concept of smart governance impacts on the increasing expenditure of the city or district since it involves high expenditure. Only those regions that have high-income levels implement this. In addition, full coordination and support from every regional stakeholder in Balikpapan City is needed, so that there is no misperception among stakeholders regarding the understanding of the smart governance concept. The integration of understanding between traditional culture and modernization often faces serious obstacles both by the implementer and the community accessing the programs offered by the smart governance concept.

\section{Literature Review}

In economics and management, there are many types and categorizations of resources as described above. Similarly, urban areas can be anonymized as an organization or company so that they have both physical and non-physical resources. As Barney points out, there are three types of resources: physical resource capital, human capital, and organizational capital resources (Barney 1991: 99-120).

Ndraha argues that based on governance theory, if local governments are considered equal to local government and governance definition is interpreted as an interaction between economic subcultures (private sector, business entity, socio-economic power), power/political subculture (local government, bureaucracy, local governance) and social subculture (NGOs, customers, socio-political power) then local government = local governance (Ndraha 2005: 57). So that in this understanding on the implementation of regional autonomy, three elements interact, namely, sub-economic culture, sub-culture of power, and sub-social culture.

The smart governance concept is one dimension in implementing a smart city. Griffinger et al. (2007: 10-14) explained six (6) dimensions in the smart city concept as the basis for implementing smart city which was then used to calculate the smart city index of seventy (70) cities in Europe. The indicator from Griffinger is used as an assessment process for cities that have implemented the smart city concept. The European Smart Cities (www.smart-cities.eu) ranks medium-size cities that meet six (6) criteria for smart cities, namely smart economy, smart people, smart government, smart mobility, smart environment, and smart living. In these concepts, the dimensions of smart governance are participation in decision making, public and social services, transparent governance, and political and strategic perfectives.

Johnston and Hansen (2011) suggest that governance infrastructure is the collection of technologies, people, policies, practices, resources, social norms, and information that interact 
to support governing activities Smart governance infrastructures augment society's ability to organize, interact, and govern.

\section{Research Method}

This research is qualitative using a descriptive approach, where the problems posed in this study are reviewed according to the theme of the concept of resources and smart governance. Qualitative research is an approach to exploring and understanding the meaning of individuals or groups ascribe to a social or human problem. The process of research involves emerging questions and procedures, data typically collected in the participant's setting, data analysis inductively building from particulars to general themes, and the researcher making interpretations of the meaning of the data. The final written report has a flexible structure. Those who engage in this form of inquiry support a way of looking at research that honours an inductive style, a focus on individual meaning, and the importance of rendering the complexity of a situation (Creswell 2014: 32).

To obtain clear information about resource support and the application of smart governance in the city of Balikpapan, researchers selected the research subjects in a purposive manner. The criteria determined by the researchers that the subjects have chosen were those who knew better and could provide information about the support of resources and the application of smart governance so that researchers could obtain information as primary data in this study. In analyzing the data researchers will use the Interactive Model as described by Miles \& Huberman (1992:20).

\section{Results}

Balikpapan City is one of the cities that responds to the development of the digital revolution by organizing innovative policies. Based on the Blueprint Smart Governance document of Smartcity of Balikpapan City Government in 2018-2020, the implementation of smart governance policies in Balikpapan City begins with the development of three (3) pillars of eGovernment, including superstructure, infostructure, and infrastructure (Balikpapan Communication and Information Agency 2017: 18). Infrastructure includes the establishment of the Balikpapan City Information and Communication Agency, related regulations both in the form of regional regulations and mayor regulations, master plans, and blueprint documents. Then the infrastructure pillar includes the construction of data centers and improvement of information and communication technology networks. The infostructure pillar, on the other hand, includes the construction of data warehouses as the foundation for information system or application integration.

The City of Balikpapan controls the direction of developing smart governance through the preparation of the Smart Governance Model which serves as a guideline for Regional Heads and leaders of regional organizations to regulate government, development and integrated community services, based on the 2016-2021 Balikpapan City Mid-Term Development Plan supported by the application Information technology. For this reason, the city of Balikpapan is developing a Blueprint for Smart Governance known as Towards Smart Cities The Balikpapan City Government 2017, which includes infrastructure, software-structures, and suprastructures based on good governance and management.

To support the realization of smart governance in the city of Balikpapan, the City Government has made various preparations, policies, implementation in various fields as 
described in the previous point. The preparation process was carried out since 2011 through the use of legal computer technology, utilization of environmentally friendly information and communication technology, and the establishment of e-Government blueprints in the application of the Balikpapan City Government. Next stage is the Development and Management phase of e-Government, and then, organizes smart governance to smart city stage. Figure 1 shows the flow of how this program works.

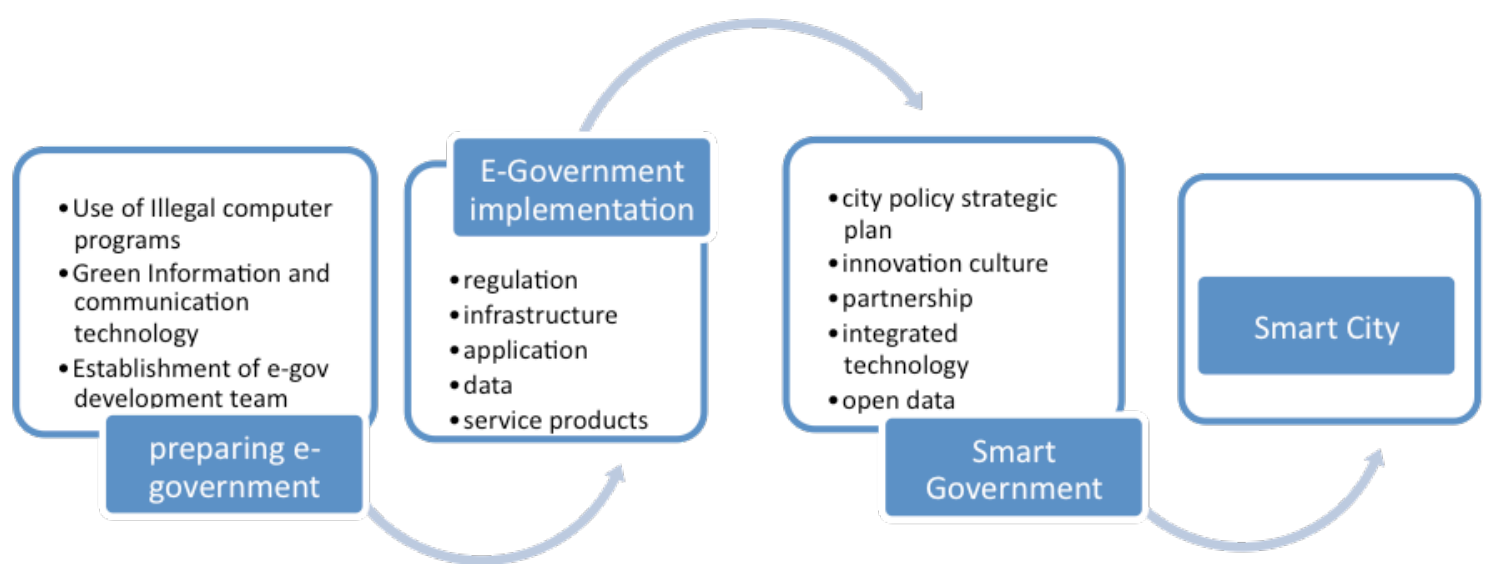

Figure 1. The phase of the Smart Governance City of Balikpapan Towards Smart city

The Preparation Phase is marked by the policy of utilizing legal computer programs so that Balikpapan government officials use legal computer programs, hence, they no longer use illegal computer programs on their computers/laptops at their workplaces. Similarly, the procurement of computers (servers, laptops, /notebooks, or PCs) is directed to buy those using legal and licensed software. It should be noted that Green Information and Communication Technology or the use of environmentally friendly information and communication technology aims to increase awareness and to change the behaviour of apparatus in the city of Balikpapan to behave environmentally friendly in the use of information and communication technology. Furthermore, the establishment of an e-Government development team is the development of plans for the implementation and management of e-Government in the City of Balikpapan.

After the preparation phase is complete, the Balikpapan City Government goes to the eGovernment implementation phase through the policy and strategy directions contained in 2016-2020 Balikpapan City Mid-Term Development Plan, with the direction of development, as follows

a. Making regulations on the implementation of e-Government.

b. Infrastructure Development for implementing e-government.

c. The development of integrated thematic applications involving related regional devices that are more focused on public services, including the application of poverty alleviation, social assistance, regional, social, disaster, investment, and information on web 3.0 based. 
d. Integration of aggregate data in the data warehouse, Management, and analysis of aggregate data in the summary Information System for regional heads and heads of regional devices and public information dissemination.

e. The products / services provided are:

1) Public service applications

2) General administration and management applications

3) Administration of legislation in the form

4) The development management application

5) Financial management applications

6) Staff management applications

When the phase of e-Government implementation went well, that started in 2018, the Balikpapan City Government carried out the Phase of holding Smart Governance, with the direction of development:

The city policy strategic plan, through the realization of the city vision that involves stakeholders, is carried out continuously by regional organizations. These are the following: (a) Develop a culture of innovation that is driven by improving the quality and strength of ICT human resources, fostering SMEs that have high competitiveness and the ability to build strategic partnerships with external parties, and realize a culture of communication; (b) develop partnership partnerships; (c) develop integrated technology; (d) develop open data with security and data protection.

The process of organizing each phase of e-government preparation and implementation has been running well until 2017. The Balikpapan City Government in the early stages of implementing smart governance in 2018 has not yet fully implemented it. This can be seen in the lack of a strengthening process in regional government resources. The results of the research described above show that strengthening is carried out by local governments through application development, infrastructure development, However, education to improve the competency of implementing apparatus still limited as well as socialization to the community regarding several programs and applications that can be used to facilitate the community service process, Table 1 shows the dimensions and sub dimensions of both smart governance and local resources. 
Table 1. Analysis of Sub-Dimensions of Research Results

\begin{tabular}{|c|c|c|c|c|}
\hline No & Variable & Dimension & Sub Dimension & Remark \\
\hline \multirow[t]{4}{*}{1} & $\begin{array}{l}\text { Smart } \\
\text { Governance }\end{array}$ & $\begin{array}{l}\text { Participation in } \\
\text { decision } \\
\text { making }\end{array}$ & $\begin{array}{l}\text { Level of community participation in decision } \\
\text { making } \\
\text { Community participation in policy } \\
\text { implementation }\end{array}$ & $\begin{array}{l}\text { Low } \\
\text { Low }\end{array}$ \\
\hline & & $\begin{array}{l}\text { Public and } \\
\text { social service }\end{array}$ & $\begin{array}{l}\text { Public and social service infrastructure } \\
\text { Available social application services } \\
\text { Use ICT } \\
\text { Community access to government services }\end{array}$ & $\begin{array}{l}\text { Good } \\
\text { Good } \\
\text { High } \\
\text { Good }\end{array}$ \\
\hline & & $\begin{array}{l}\text { Transparent } \\
\text { governance }\end{array}$ & $\begin{array}{l}\text { Availability of government information } \\
\text { Transparency of apparatus } \\
\text { Transparency of government management }\end{array}$ & $\begin{array}{l}\text { Good } \\
\text { Good } \\
\text { Good }\end{array}$ \\
\hline & & $\begin{array}{lr}\text { Political and } \\
\text { strategic } \quad \& \\
\text { perspective }\end{array}$ & $\begin{array}{l}\text { Basic policies for implementing smart } \\
\text { governance } \\
\text { The government's perspective on smart } \\
\text { governance }\end{array}$ & $\begin{array}{l}\text { Good } \\
\text { High }\end{array}$ \\
\hline \multirow[t]{3}{*}{2} & $\begin{array}{l}\text { Local } \\
\text { resources }\end{array}$ & $\begin{array}{l}\text { Local } \\
\text { government }\end{array}$ & $\begin{array}{l}\text { Institutional } \\
\text { Application creation and management budget } \\
\text { Manpower competency management }\end{array}$ & $\begin{array}{l}\text { Low } \\
\text { Low } \\
\text { Low }\end{array}$ \\
\hline & & $\begin{array}{l}\text { Service } \\
\text { provider }\end{array}$ & $\begin{array}{l}\text { Availability of service providers } \\
\text { The existence of a partnership }\end{array}$ & $\begin{array}{l}\text { Good } \\
\text { Good }\end{array}$ \\
\hline & & $\begin{array}{l}\text { Community } \\
\text { user }\end{array}$ & $\begin{array}{l}\text { Community response to application users } \\
\text { Community use of the application provided }\end{array}$ & $\begin{array}{l}\text { Good } \\
\text { Low }\end{array}$ \\
\hline
\end{tabular}

Based on the table above, it can be seen that the implementation of Smart Governance in Balikpapan City has been going well where the sub-dimensions of Public and Social Service, Transparent Governance, and Political Strategic and Perspective appear to be implemented and supported well, except for, participation in decision making. The Balikpapan City Government has committed to preparing and implementing smart governance both in terms of policy support, infrastructure, and the use of online applications. Constraints faced are low community participation in supporting decision-making policies. The low participation of the people of Balikpapan is also seen in several literature, and online news (for example, http://balikpapan.prokal.co) which shows the need to promote communication with the community through the dissemination of various policies of the Balikpapan City government so that people can understand the benefits of government policies and be able to increase the participation of its people.

In the process of strengthening local government resources in supporting the implementation of smart governance in the city of Balikpapan, it has been seen that so far the process has not been optimal. The smart governance development policy as implemented is still not supportive of the institutional sub-dimensions, budgets and resources of the application management apparatus, and the community's use of existing applications.

In terms of institutions, there is no container as a command center in the city of Balikpapan even though the Balikpapan City Communication and Information Office has been formed, but it has not organized and collected various innovations and applications from each agency. Interestingly, it is linked to the website http://balikpapan.go.id/instansi/, but after opening, it will return to the web address http://balikpapan.go.id/instansi/.

Of the 18 service web links in Balikpapan City, six (6) links are not open and often they return to the agency link http://balikpapan.go.id/instansi/. From the 10 Link Bodies listed in the website link of the Balikpapan City agency, http://balikpapan.go.id/instansi/, five (5) links are 
not active and return to the agency link. The lack of strengthening of institutions can result in a collapse of the process of implementing smart governance launched by the City of Balikpapan, especially so that links of the Balikpapan City Communication and Information Office are still not active along with other agencies.

Furthermore, the budget provided in the 2017 APBD for the allocation of Information and Communication Technology is under 1\%, still far compared to the ideal $2 \%$ budget posture, according to Earnest and Young's best practices.

Likewise, the sub-dimensions of apparatus resources are still lacking due to frequent mutations and promotions that handles the application. This does not help at all, in fact, retraining is necessary for this purpose.

Similarly, the condition of society is still lacking in the use of government services and social services. There are around $87.88 \%$ of the people of Balikpapan city who use cellular phones, and around $52.11 \%$ who access social media (BPS, 2017), but only around $0.31 \%$ or +1000 people download online applications regarding government services and services. local social. This is based on the number of users who download local applications such as TMC, Balikpapan and I Balikpapan kafeku. Other applications only downloaded by +500 and 10 users. This should be a serious concern for the Balikpapan City Government because of the support of the large private internet service providers for Balikpapan City must be accompanied by the development of government resources and community resources. For government resources, the arrangement of the implementation of smart governance is just entering its initial stage so there are still many deficiencies.

In developing smart governance in the city of Balikpapan in 2018-2022, the city government directs smart services, smart experience, and smart business through the management of integrated information and communication technology-based on good management governance. It prioritized on the integration of data and information systems in administering government affairs, both mandatory, optional affairs and supporting elements that exist today and as well as those that will be developed in the future. There is also low subdimensions of community participation in decision-making, and support from elements of local government and the community. Hence, the local government of Balikpapan City needs to address this issue by strengthening these sub-dimensions, as shown in Table 2. 
Table 2. Sub-Dimensional Gap Analysis

\begin{tabular}{|c|c|c|c|c|}
\hline No & Sub Dimension & Condition & Expectation & Recommendation \\
\hline 1 & $\begin{array}{l}\text { Level of } \\
\text { community in } \\
\text { participation in } \\
\text { decision making }\end{array}$ & Low & Increase & 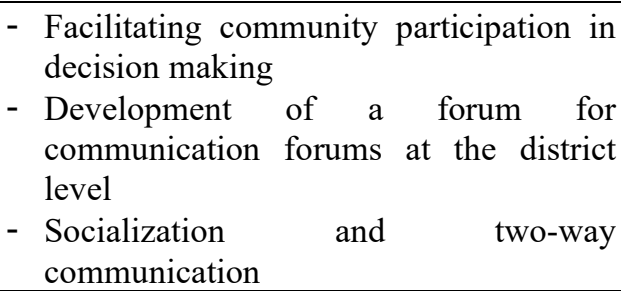 \\
\hline 2 & $\begin{array}{l}\text { Community } \\
\text { participation in } \\
\text { policy } \\
\text { implementation }\end{array}$ & Low & Increase & $\begin{array}{l}\text { - Facilitating community participation in } \\
\text { policy implementation } \\
\text { - Development of a forum for } \\
\text { communication forums at the district } \\
\text { level } \\
\text { - Balanced socialization and two-way } \\
\text { communication }\end{array}$ \\
\hline 3 & Institutional & Low & Increase & $\begin{array}{l}\text { - Preparation of ICT guidelines involving } \\
\text { all regional apparatus } \\
\text { - Establishing a command center as an } \\
\text { information service center and consulting } \\
\text { and coordinating ICT } \\
\text { - Improving the organization of regional } \\
\text { apparatus towards an adaptive learning } \\
\text { organization }\end{array}$ \\
\hline 4 & $\begin{array}{l}\text { Application } \\
\text { creation and } \\
\text { management } \\
\text { budget }\end{array}$ & Low & Increase & $\begin{array}{l}\text { - Increasing ICT budgeting at a minimum } \\
\text { of } 3 \% \text { from the APBD }\end{array}$ \\
\hline 5 & $\begin{array}{l}\text { Manpower } \\
\text { Competency } \\
\text { Management }\end{array}$ & Low & Increase & $\begin{array}{l}\text { - Improving the quality and quantity of } \\
\text { ICT through training and application of } \\
\text { functional positions in ICT Human } \\
\text { resource }\end{array}$ \\
\hline 6 & $\begin{array}{l}\text { Community use of } \\
\text { the application } \\
\text { provided }\end{array}$ & Low & Increase & $\begin{array}{l}\text { - Development of online application-based } \\
\text { SMEs that have high competitiveness and } \\
\text { the ability to build strategic partnerships } \\
\text { with external parties } \\
\text { - Facilitation with online application-based } \\
\text { SMEs for the development of innovative } \\
\text { products that provide competitive } \\
\text { advantages } \\
\text { - Community socialization regarding SME } \\
\text { products based on superior and } \\
\text { innovative online applications } \\
\text { - Building partnerships between Regional } \\
\text { Apparatus Organization and private } \\
\text { parties to develop online applications that } \\
\text { are innovative and needed by the } \\
\text { community }\end{array}$ \\
\hline
\end{tabular}

Based on the gap analysis above, it is expected that it can provide input for the regional government and the people of Balikpapan City in organizing smart governance to meet the needs of the community. The implementation of smart governance in serving the needs of the community can be carried out well if coupled with strengthening local government resources which include local government, the private sector, and the community through the use of information and communication technology to lead a quality community life and participatory government. 
For this reason, Balikpapan City Government needs to make policies and programs to strengthen local government resources in supporting the implementation of smart governance. Strengthening the area's resources which are divided into local government and community sectors are as follows:

1. Regional Government Sector

a) Preparation of information and communication technology guidelines involving all regional authorities

b) Establishment of a command center as a center for information services and consultation and coordination of information and communication technology

c) Improving the organization of regional equipment towards an adaptive learning organization

d) Increasing information and communication technology budgeting at a minimum of 3\% from the Local Revenue and Expenditures Budget

e) Increasing the quality and quantity of information and communication technology human resources through training and implementation of functional positions.

2. Community Sector

a) Facilitate community participation in decision making

b) Development of communication forum forums at the kelurahan level

c) Facilitating community participation in policy implementation

d) Development of a forum for communication forums at the kelurahan level

e) Balanced two-way socialization and communication in the implementation of development, especially starting from the kelurahan level.

Fostering SMEs based on online applications that have high competitiveness and the ability to build strategic partnerships with external parties

a) Facilitation with online application-based SMEs for the development of innovative products that provide competitive advantages

b) Public awareness about SME products based on superior and innovative online applications.

c) Building partnerships between regional apparatus organization and the private sector to develop online applications that are innovative and needed by the community. 


\section{Conclusion}

The implementation of smart governance in Balikpapan City runs well in the dimensions of public and social service and transparent governance, and supported by the basic preparation of policies and perfective governance in the implementation of smart governance on the politicalstrategic dimension and perspective. Nonetheless, the implementation of the smart governance is still low especially in decision making at the level of community. There is also low participation in decision-making and community participation in policy implementation.

The condition of regional resources in the implementation of smart governance in Balikpapan City is still low and lacking in terms of institutions, budgets and management apparatus in the dimensions of regional governance, and the low use of community applications for the applications provided, even though they have been supported in the dimensions of service providers and good the user's response to the online service application. The implementation of smart governance in Balikpapan City that serve the needs of the community can be implemented well if coupled with strengthening local government resources that include institutions, budgets and IT apparatus on the dimensions of local government, as well as with increasing community participation and community use of applications in the community dimension. 


\section{References}

Balikpapan.go.id, Balikpapan raih peringkat kedua kota cerdas 2015, avaiable at: http://balikpapan.go.id/berita/detail/6156/balikpapan-raih-peringkat-kedua-kotacerdas-2015.

Balikpapan.go.id, bukktikan diris sebagai kota cerdas, avaiable at: http://balikpapan.prokal.co/read/news/171114-buktikan-diri-sebagai-kota-cerdas.

Balikpapan Mayor Regulation Number 55 Year 2016 concerning the Organizational Structure, Job Description and Function of the Office of Communication and Information.

Barney, J.B. (1991). Firm resources and sustained competitive advantage. Journal of Management, 17(1): 99-120, https://journals.sagepub.com/doi/10.1177/014920639101700108.

Bouskela, M. et al. (2016). The Road toward Smart Cities, Migrating from Traditional City Management to the Smart City, Inter-American Development Bank (IDB), https://publications.iadb.org/en/road-toward-smart-cities-migrating-traditional-citymanagement-smart-city.

Central Bureau of Statistics of Balikpapan. (2017). Balikpapan City People's Welfare Statistics Year Book 2017. Indonesia.

Creswell, J.W. (2014). Research Design: Qualitative and Quantitative Approaches. Thousand Oaks, CA: SAGE Publications.

Decision of the Mayor of Balikpapan, number 188.4594/2013 about concerning Determination of e-Government Blueprint in the Field of Application of the City of Balikpapan.

Decision of the Mayor of Balikpapan, number 18.45-234/2015 about the e-Government Development and Management Team d Balikpapan City Government Environment.

Johnston, E.W. \& D.L. Hansen. (2011). Design Lessons for Smart Governance Infrastructures, Transforming American governance: Rebooting the public square, pp 1-30.

Mayor Regulation Number 12 of 2016 about Implementation of e-Government with the Scope of Planning, Policy, Institutional, Information Systems, and ICT Infrastructure.

Mayor Regulation Number 13 of 2016 about Providing Internet Services.

Miles, M.B \& A.M. Huberman. (1992). Analisis Data Kualitatif. Jakarta : UI Press.

Ndraha, T. (2005). Keybernology, Sebuah carta pembaharuan,Sirao Credentia Center, Banten.

Prokal.co.balikpapan Target Meleset, Partisipasi Pemilih Hanya 64,6 Persen, news: 30-062018, avaiable at: http://balikpapan.prokal.co/read/news/233397-target-melesetpartisipasi-pemilih-hanya-646-persen.html. 
Regional Regulation of City of Balikpapan Number 2 of 2017 about Implementation of Communication and Information Technology. 